\title{
Analysis of seasonal variation of indoor radon concentration in Tehri Garhwal, Northern India
}

\author{
M S Kandari ${ }^{1}$ and R C Ramola ${ }^{2^{*}}$ \\ ${ }^{1}$ Department of Physics, Govt. P G Collage Kotdwara, Pauri Garhwal-246 149 , \\ Uttarakhand, India \\ 2Department of Physics, H N B Garhwal University, Badshahi Thaul Campus, \\ Tehri Garhwal-249 199, Uttarakhand, India \\ E-mail : rcramola@bsnl.in
}

Abstract : The seasonal variation analysis of indoor radon has been carried out in the hilly region of Tehri Garhwal, Northern India by using LR-115 Type II, plastic track detector. In the analysis the winter/summer ratio radon values were found to vary from 0.63 to 1.64 and 1.02 to 1.22 for cemented houses and mud houses, respectively. Over all the average value of winter/summer ratio was found maximum in both cemented and mud houses respectively.

Keywords : Radon, houses, seasons

PACS Nos. : 92.60.Sz, 89.60.-k

\section{Introduction}

Man has been exposed to natural radiation since his appearance on earth. However, the major contribution to the average annual as received by mankind still comes from natural radiation. Keeping in view of this, a study of seasonal variation of radon in the Tehri Garhwal has been carried out. In India, annual average radon concentration is $33.2 \mathrm{~Bq} / \mathrm{m}^{3}$ [1] against the global average of $40 \mathrm{~Bq} / \mathrm{m}^{3}$ [2]. Most of the indoor radon data in India is scattered and survey carried out in some areas focuses particularly on the effect of seasonal variation in indoor radon level. But the situation is different for hilly region in India, as these areas have cold climate for most of the time in the year. Our study area falls in such a region. It is therefore necessary to measure the radon concentration in different seasons. Unusual weather condition, air in the dwellings, construction material [3] and similar others are to be taken into account for extrapolation to an annual average value of the measured radon concentration.

\footnotetext{
* Corresponding Author
} 


\section{Experimental method}

In the study, the dwellings of hill region were chosen as mud and cemented houses in residential and work places. Bare mode method was used to measure radon concentration. Radon/thoron and their progeny were measured by using LR-115 Type II, plastic track detector. Small pieces of detector of size $2.5 \times 2.5 \mathrm{~cm}$ were fixed in a glass plate and these were suspended inside the house at a height about 2 meter from the floor for three months. The films were then removed, etched and counted for track density. The recorded track density was converted to radon concentration by using appropriate calibration factor [4].

\section{Results and discussion}

The comparison of observed radon values in different seasons are shown in Tables 1 and 2. It was observed that the average indoor radon concentration in winter is higher than that in any other season, both in mud and cemented houses. The winter/summer, winter/

Table 1. Seasonal variation of indoor radon concentration in cemented houses.

\begin{tabular}{lcccc}
\hline Place & $\begin{array}{c}\text { Number of } \\
\text { measurements }\end{array}$ & \multicolumn{3}{c}{$\begin{array}{c}\text { Ratio of indoor radon } \\
\text { concentration }\end{array}$} \\
\cline { 3 - 5 } & & W/S & W/R & W/A \\
\hline Tehri & 7 & 1.40 & 1.44 & 1.05 \\
New Tehri & 8 & 1.16 & 1.15 & 1.17 \\
Padiyargaon & 1 & 0.63 & 0.59 & 0.64 \\
Nail & 2 & 1.25 & 1.23 & 1.15 \\
Chamba & 3 & 1.64 & 1.91 & 1.65 \\
Dikholgaon & 1 & 1.22 & 1.09 & 0.86 \\
Thanegaon & 1 & 1.10 & 0.89 & 1.02 \\
Serai & 2 & 1.00 & 1.00 & 0.78 \\
Uppu & 3 & 1.00 & 1.21 & 0.85 \\
Chham & 3 & 1.22 & 0.96 & 1.10 \\
Koti Colony & 2 & 1.49 & 1.11 & 0.86 \\
Chauras & 2 & 1.12 & 0.80 & 1.18 \\
Nageshwar Saur & 4 & 1.00 & 1.17 & 0.94 \\
Pratapnagar & 2 & 1.32 & 0.92 & 0.96 \\
Nagni & 2 & 1.37 & 1.51 & 1.27 \\
Narendranagar & 2 & 0.76 & 0.53 & - \\
Lambgaon & 1 & 1.34 & 1.11 & 1.88 \\
Ghansali & 3 & 1.08 & 1.56 & 1.27 \\
Chamiyala & 1.09 & 0.98 & 1.53 \\
Ghonti & 2 & 1.27 & 0.89 & 1.53 \\
\hline Average & & 1.16 & 1.05 & 1.11 \\
\hline S- & 2 & &
\end{tabular}

W-Winter, A-Autumn, S-Summer, and R-Rainy 
rainy and winter/autumn ratios were found to vary from 0.51 to 2.13 (average 0.63 to 1.64), 0.58 to 2.26 (average 0.59 to 1.56 ) and 0.56 to 2.29 (average 0.64 to 1.88 ), respectively, in cemented houses. In mud houses, the winter/summer, winter/rainy and winter/autumn ratios were found to vary from 0.59 to 3.47 (average 1.02 to 2.22), 0.50 to 4.24 (average 0.88 to 1.47 ) and 0.41 to 5.07 (average 0.91 to 2.22), respectively; the overall average value of winter/summer ratio was found to be maximum in both cemented and mud houses, being 1.16 and 1.43 respectively. As such, the average radon level was found to be maximum in winter and minimum in summer. However, in selected houses the winter/summer ratio was found to be less than one i.e. higher radon value was recorded in summer than in the winter. The abnormal behavior was mainly in school, which remains closed for a long time during summer. A few residential houses have also recorded higher radon level in summer, which perhaps is due to the fact that the occupants of the house could have shifted temporarily to other places for short duration.

\subsection{Cemented houses:}

Residential : The result of radon measurements for different seasons in residential houses shows that $39 \%$ houses in the autumn and $29 \%$ houses both in the summer and rainy seasons have radon level in the range of 101 to $150 \mathrm{~Bq} / \mathrm{m}^{3}$. On the other hand, the corresponding numbers of houses are reverse for radon level in the range of 51 to $100 \mathrm{~Bq} /$

Table 2. Seasonal variation of indoor radon concentration in mud houses.

\begin{tabular}{lcccc}
\hline Place & $\begin{array}{c}\text { Number of } \\
\text { measurements }\end{array}$ & \multicolumn{3}{c}{$\begin{array}{c}\text { Ratio of indoor radon } \\
\text { concentration }\end{array}$} \\
\cline { 3 - 5 } & & W/S & W/R & W/A \\
\hline Tehri & 3 & 2.2 & 1.30 & 1.30 \\
Nail & 6 & 1.02 & 1.23 & 0.99 \\
Manjur & 3 & 1.09 & 0.98 & 0.92 \\
Dikholgaon & 2 & 1.23 & 1.14 & 1.03 \\
Thanegaon & 1 & 1.48 & 1.09 & 1.07 \\
Sabligaon & 2 & 1.81 & 1.00 & - \\
Malideval & 3 & 1.80 & 1.36 & 1.23 \\
Rajgaon & 1 & 1.26 & 1.01 & 1.05 \\
Uppu & 2 & 1.12 & 1.09 & 0.91 \\
Dang & 2 & 1.45 & 0.88 & 1.47 \\
Changora & 4 & 1.46 & 1.47 & 1.40 \\
Pratapnagar & 2 & 1.27 & 1.57 & 1.34 \\
Ghonti & 1 & 1.20 & 1.74 & 2.22 \\
\hline Average & & 1.42 & 1.22 & 1.25 \\
\hline
\end{tabular}

W-Winter, A-Autumn, S-Summer, and R-Rainy 
$\mathrm{m}^{3} .57 \%$ houses in the summer, $43 \%$ houses in the rainy season, $29 \%$ houses in the winter season and $39 \%$ houses in the autumn have the radon level in this range. The number of houses having radon values exceeding $200 \mathrm{~Bq} / \mathrm{m}^{3}$ are relatively less i.e. $11 \%$ and $3.5 \%$ in the winter and the summer respectively, and $7 \%$ in the both the autumn and rainy seasons. Above all, the indoor radon levels are found higher during the winter and autumn than those in the summer and the rainy season.

Work places: The results of radon concentration for different seasons in the houses used as working places (offices, schools etc.) show that $34 \%$ of houses in winter, $27 \%$ in autumn, $21 \%$ houses in summer and $14 \%$ in the rainy season have recorded the radon level in the range of 151 to $200 \mathrm{~Bq} / \mathrm{m}^{3}$. On the other hand $38 \%$ houses in the summer have recorded higher radon levels in the winter for both categories of houses. Radon levels were observed higher in work places than those in residential houses. Since the work place remains closed during weekends, holidays and vacations, the air is accumulated inside the room due to poor ventilation condition.

\subsection{Mud houses :}

Residential : The result of radon levels for different seasons in the residential houses shows that $23 \%$ houses in winter, $30 \%$ houses in autumn, $10 \%$ houses in summer and $16 \%$ in the rainy season have radon levels in the range of 151 to $200 \mathrm{~Bq} / \mathrm{m}^{3}$. On the other hand the frequency of the houses increases for the range of 51 to $100 \mathrm{~Bq} / \mathrm{m}^{3}$, which is maximum (40\%) for the summer and minimum (26\%) for both the winter and the rainy season.

Work places: The results of radon measurements for different seasons in the houses used as work places show that $56 \%$ houses in the winter have recorded the radon levels in this range 151 to $200 \mathrm{~Bq} / \mathrm{m}^{3}$, while the number of houses having radon levels in this range are $11 \%, 27 \%$ and $22 \%$ in the summer, the autumn and rainy season, respectively. For most of the seasons, the radon levels are recorded higher in the range of 51 to 100 $\mathrm{Bq} / \mathrm{m}^{3}$.

\section{Conclusions}

Radon level was found to be higher in mud houses than in cemented houses. It also depends on ventilation condition of the room. Radon level in mud houses suggests that the indoor radon level is influenced by the building material and mode of construction of the houses. Radon levels were recorded high in winter and autumn and low in the summer and rainy season. However, it is found to be the highest in winter and lowest in the summer. The indoor radon levels in the areas were found to be above average but well below the action levels set by different countries and institutions. 


\section{References}

[1] T V Ramachandran Proc. 10th National Symposium on SSNTDs, Kurukshetra p11 (1996)

[2] UNSCEAR United Nations Scientific Committee on the Effect of Atomic Research. United Nations New York (1993)

[3] R C Ramola, R B S Rawat and M S Kandari Proc. 4th National Symposium on Environ, Madras, India pp 199-200 (1995)

[4] R C Ramola, R B S Rawat, M S Kandari, T V Ramachandran, K P Eappen and M C Subba Ramu Indoor Built. Environ. 5363 (1996) 